\title{
The effect of different treatments for early-lactation hyperketonemia on liver triglycerides, glycogen, and expression of key metabolic enzymes in dairy cattle
}

\author{
S. Mann, ${ }^{* 1}$ F. A. Leal Yepes,† J. J. Wakshlag,‡ E. Behling-Kelly, ${ }^{*}$ and J. A. A. McArt* \\ *Department of Population Medicine and Diagnostic Sciences, \\ †Department of Animal Science, and \\ ‡Department of Clinical Sciences, Cornell University, Ithaca, NY 14853
}

\begin{abstract}
Despite the widespread use of treatments for postpartum hyperketonemia in dairy cows, there is currently a lack of evidence comparing their effects on both the resolution of hyperketonemia and the potential effects on the liver of affected animals. The objective of our work was to investigate the effect of commonly used hyperketonemia treatments on hepatic triglyceride and glycogen content as well as on the mRNA and protein abundance of key enzymes involved in gluconeogenesis, ketogenesis, and lipid metabolism. Multiparous Holstein cows between 3 and $9 \mathrm{~d}$ in milk were screened 3 times per week and enrolled in the study when wholeblood $\beta$-hydroxybutyrate concentrations measured $\geq 1.2 \mathrm{mmol} / \mathrm{L}$. Cows were randomly allocated to 1 of 4 groups: (1) $500 \mathrm{~mL}$ of a 50\% D-glucose solution intravenously once a day for $3 \mathrm{~d}(\mathrm{n}=8),(2) 300 \mathrm{~mL}$ of propylene glycol orally once a day for $3 \mathrm{~d}(\mathrm{n}=8)$, (3) $500 \mathrm{~mL}$ of a $50 \%$ D-glucose solution intravenously and $300 \mathrm{~mL}$ of propylene glycol orally once a day for $3 \mathrm{~d}(\mathrm{n}=8)$, or (4) an untreated control group ( $\mathrm{n}=$ 8). Liver biopsies were taken on the day of enrollment as well as on the day following completion of treatments. Liver triglyceride and glycogen content were determined by colorimetric and fluorometric methods, respectively. Gene and protein expression of pyruvate carboxylase, phosphoenolpyruvate carboxykinase 1, glucose-6-phosphatase, 3-hydroxy-3-methylglutarylCoA synthase 2, acetyl-CoA carboxylase, and carnitine palmitoyltransferase $1 \mathrm{~A}$ were compared between groups and time points using quantitative reverse transcriptase PCR and Western blotting techniques, respectively. In addition, the ratio of light chain 3B II:I was determined
\end{abstract}

Received June 20, 2017.

Accepted October 10, 2017.

${ }^{1}$ Corresponding author: sm682@cornell.edu by Western blotting. Plasma samples from both time points for each enrolled cow were submitted for chemistry analysis. Data were analyzed using a repeatedmeasures ANOVA taking into account the paired nature of the data, and differences between all groups and time points were controlled for multiple comparisons using the Tukey procedure. No difference was found in triglyceride or glycogen concentration between treatment groups. The gene expression of pyruvate carboxylase decreased in the group receiving both treatments, whereas protein expression of this enzyme increased in all groups over time. The autophagy marker light chain 3B II:I decreased in the group receiving both glucose and propylene glycol. No other changes in gene or protein expression of key hepatic enzymes were associated with treatments. We conclude that intravenous glucose and oral propylene glycol, commonly used treatments for ketosis in postpartum dairy cows, administered alone or in combination for a duration of $3 \mathrm{~d}$ did not have important beneficial or detrimental effects on selected indicators of liver composition and function in cows with hyperketonemia.

Key words: ketosis, liver, triglyceride, glycogen, enzyme

\section{INTRODUCTION}

Hyperketonemia is characterized by an excessive concentration of ketone bodies in blood and is a highly prevalent and costly metabolic disorder of postpartum dairy cows (McArt et al., 2015; Raboisson et al., 2015; Gohary et al., 2016). In an attempt to reduce the risk for negative health and production outcomes, cows that develop hyperketonemia (defined as a wholeblood BHB concentration of $\geq 1.2 \mathrm{mmol} / \mathrm{L}$; McArt et al., 2013) are identified using herd screening programs and treated early in the course of the disorder (Ospina et al., 2013; Tatone et al., 2016; Gordon et al., 2017). Among the most commonly used treatments is daily administration of intravenous glucose and oral pro- 
pylene glycol alone or in combination. Despite their widespread use, there is currently a lack of evidence comparing the effects of such treatments on the resolution of hyperketonemia and on the potential effects on the liver of affected animals. The liver plays an important role in the successful transition to lactation (Graber et al., 2010), and treatments for hyperketonemia aim to maintain or improve hepatic gluconeogenesis and glucose status as well as prevent or reduce the accumulation of triglycerides in the liver (Herdt and Emery, 1992; Gordon et al., 2013).

In the liver, propylene glycol metabolism increases the availability of oxaloacetate from pyruvate and thus provides a source for this important intermediary in the Krebs cycle often lacking in cows with ketosis (Nielsen and Ingvartsen, 2004). In addition, it is converted to glucose from propionate via the gluconeogenic pathway in the liver (Nielsen and Ingvartsen, 2004), and administration of propylene glycol may increase mRNA expression of gluconeogenic enzymes in the liver (Zhang et al., 2015). In contrast, intravenous glucose adds directly to the available glucose pool and circumvents a need for hepatic gluconeogenesis. As the expression of gluconeogenic enzymes is controlled by substrate availability and energy balance, one concern is that a surplus of glucose supply to the liver may have detrimental consequences if it leads to downregulation of gluconeogenic enzymes (Al-Trad et al., 2010b).

Successful physiologic adaptation to lactation also requires an upregulation of enzymes involved in lipid metabolism and $\beta$-oxidation (Bauman and Currie, 1980), which are often overwhelmed in cows with ketosis, leading to an accumulation of fat in the liver (Herdt, 2000; Dann et al., 2005). Ideally, successful treatment or prevention of hyperketonemia controls or reduces the rate at which triglycerides are deposited in the liver by reducing lipolysis and increasing the oxidation of fatty acids in the liver.

To date, the effect of the commonly used hyperketonemia treatments (oral propylene glycol and intravenous glucose) on liver function and hepatic lipid content in the peripartum period have not been compared in a randomized controlled trial. The primary objective of our study was thus to determine the effect of these treatments on the expression of select key enzymes that regulate hepatic gluconeogenesis, ketogenesis, and lipid metabolism. In addition, we wanted to determine a possible association of treatments with liver triglyceride and glycogen content as well as with indicators of liver function determined by plasma chemistry analysis. We hypothesized that common treatments for hyperketonemia vary in their effects on liver metabolism based on the different metabolic pathways involved in their mode of action.

\section{MATERIALS AND METHODS}

All procedures were evaluated and approved by the Cornell University Institutional Animal Care and Use Committee (protocol no. 2015-0097). Housing, management, and enrollment of animals was as previously described (Mann et al., 2017). In brief, multiparous Holstein cows between 3 and 9 DIM at the Cornell University Ruminant Center in Harford, New York, were screened for blood BHB concentrations after the morning milking 3 times per week. Cows were enrolled in 1 of 4 treatment groups following a randomized block design when whole-blood BHB concentration was $\geq 1.2$ $\mathrm{mmol} / \mathrm{L}$ and were moved to individual sawdust-bedded tiestalls with feed bins until the end of the study period at 21 DIM. A TMR was offered ad libitum; cows were fed once daily at $0900 \mathrm{~h}$, and amounts fed were adjusted to allow for a minimum of $5 \%$ refusals.

\section{Treatments}

Cows were allocated to 1 of 4 groups using a randomized block design: (1) $500 \mathrm{~mL}$ of a $50 \%$ D-glucose solution (dextrose $50 \%$ injection, VetOne, Boise, ID) intravenously once a day for $3 \mathrm{~d}(\mathbf{G L U} ; \mathrm{n}=8)$, (2) $300 \mathrm{~mL}$ of propylene glycol ( $100 \%$ propylene glycol, VetOne) orally once a day for $3 \mathrm{~d}(\mathbf{P G} ; \mathrm{n}=8)$, (3) $500 \mathrm{~mL}$ of a $50 \%$ D-glucose solution intravenously and $300 \mathrm{~mL}$ of propylene glycol orally once a day for $3 \mathrm{~d}(\mathbf{G L U}+\mathbf{P G}$; $\mathrm{n}=8$ ), or (4) an untreated control group (CTRL; $\mathrm{n}=$ 8). Treatments were always administered immediately before the morning feeding at the same time every day. Propylene glycol was administered as a drench immediately before morning feeding using a manual drenching gun (Neogen, Lexington, KY). After warming to body temperature in a water bath, glucose was administered as a rapid infusion through the jugular catheter. Blood samples were taken into evacuated tubes with 158 units of sodium heparin (Becton Dickinson, Franklin Lakes, NJ) at $0,1,2,4,8,12,24,36,48$, and $72 \mathrm{~h}$ relative to treatment. Samples at 24 and $48 \mathrm{~h}$ were taken immediately before administration of the second and third treatments, respectively. All blood samples were placed on ice, and heparinized plasma was obtained within 60 min of sampling by centrifugation at 2,800 $\times g$ for 20 min at $4^{\circ} \mathrm{C}$. Whole-blood concentrations of $\mathrm{BHB}$ and plasma concentrations of fatty acids, glucose, glucagon, and insulin were determined as previously described (Mann et al., 2017). Heparinized plasma samples for 0 - and 72-h time points were submitted to the Clinical Pathology Laboratory within the Animal Health Diagnostic Center at Cornell University (Ithaca, NY) for blood chemistry analysis (Roche P modular chemistry analyzer, Roche Diagnostics, Indianapolis, IN). 


\section{Liver Biopsy}

Liver biopsies were obtained from all cows immediately before the first treatment $(0 \mathrm{~h})$ as well as on the day after the last treatment $(96 \mathrm{~h})$. Cows received a single dose of 0.003 to $0.005 \mathrm{mg} / \mathrm{kg}$ of acepromazine maleate (VetOne) intravenously to achieve light sedation. The biopsy site was chosen in the right 11th intercostal space after confirmation of correct placement with ultrasonography using a $7.5-\mathrm{MHz}$ linear array transducer (Ibex Pro, E.I. Medical Imaging, Loveland, CO), and the site was prepared surgically. Local anesthesia was achieved by infiltration of $10 \mathrm{~mL}$ of lidocaine $2 \% \mathrm{HCl}$ (Vet One) into the muscular and subcutaneous tissues. A stab incision of approximately $1.5 \mathrm{~cm}$ was made with a scalpel blade, and the biopsy trocar was introduced into the liver in the direction of the left elbow. Approximately 1 to $2 \mathrm{~g}$ of liver tissue was harvested with a trocar and cannula instrument as previously described (Hughes, 1962), blotted on sterile gauze to remove excess blood, aliquoted into 2-mL cryovials (Nalgene, VWR, Radnor, PA), and frozen immediately in liquid nitrogen. The stab incision was closed with a single surgical staple (Vista stapler, 3M, Maplewood, MN). Samples were transported in liquid nitrogen to the laboratory, where they were stored at $-80^{\circ} \mathrm{C}$ until further analysis. Cows received $1.1 \mathrm{mg} / \mathrm{kg}$ of flunixin meglumine (Prevail, VetOne) intravenously for minor pain relief on both days immediately following the procedure. Enzymes of interest for the measurement of gene expression and protein abundance were chosen to describe possible changes in gluconeogenesis (PC, PCK1, G6PC), ketogenesis (HMGCS2), and lipid metabolism (ACC, CPT1A).

\section{Gene Expression}

For extraction of RNA from all samples, $30 \mathrm{mg}$ of liver tissue was weighed from each sample and placed into $600 \mu \mathrm{L}$ of lysis buffer and homogenized using a tissue homogenizer (VDI 12, VWR). Homogenized samples were processed according to the manufacturer's instructions (RNeasy mini kit, Qiagen, Hilden, Gemany). Concentration, integrity, and purity of RNA were assessed using a NanoDrop Once C spectrophotometer (Thermo Fisher Scientific, Waltham, MA). Concentrations ranged from 600 to $1,800 \mathrm{ng} / \mu \mathrm{L}$. All A260/280 ratios were found to be between 2.00 and 2.12. For reverse transcription, $5 \mu \mathrm{g}$ of total RNA was used in each reaction (Superscript IV first strand system, Life Technologies, Carlsbad, CA). All Taqman probes for genes of interest were selected to span exon junctions and not detect genomic DNA and were purchased from Applied Biosystems (Foster City, CA):
acetyl-CoA carboxylase $\alpha$ (ACC1; assay Bt03213383), pyruvate carboxylase $(P C$; assay Bt03244522), cytosolic phosphoenolpyruvate carboxykinase (PCK1; assay Bt03224290), glucose-6-phosphatase ( $G 6 P C$; assay Bt03242914), mitochondrial 3-hydroxy-3-methylglutaryl-CoA-synthase 2 (HMGCS2; assay Bt03233807), and carnitine palmitoyl-transferase 1 (CTP1A; custom made). In addition, 3 reference genes were selected: TATA box binding protein (TBP; Bt03241948), large ribosomal protein P0 (RPLP0; Bt03218086), and eukaryotic translation initiation factor 3 subunit K (EIF3K; assay Bt03226565; Bonnet et al., 2013; Ostrowska et al., 2014). Reactions were prepared in triplicate according to recommendations for the use of Taqman Gene Expression master mix on a StepOne Plus instrument (Applied Biosystems) with 10\% of the reaction volume consisting of 7 -fold diluted cDNA and set to 40 cycles of $95^{\circ} \mathrm{C}$ for $15 \mathrm{~s}$ (denaturation) and $1 \mathrm{~min}$ at $60^{\circ} \mathrm{C}$ (annealing and extension). Control reactions without the addition of template were included on every plate. A single pool of RNA from a liver sample harvested in this experiment was used to generate the calibrator cDNA used on all plates for the relative gene expression following the $2^{-\Delta \Delta \mathrm{Ct}}$ method, and results are expressed as relative quantity.

\section{Protein Expression}

For the preparation of protein lysates for immunoblotting, $30 \mathrm{mg}$ of liver tissue was homogenized in $500 \mu \mathrm{L}$ of lysis buffer as previously described (Mann et al., 2016). In brief, frozen tissue was mechanically disrupted in ice-cold radioimmunoprecipitation assay buffer with the addition of phosphatase and protease inhibitor cocktail (Halt, Thermo Fisher Scientific) using a tissue homogenizer (VDI12, VWR) and subsequently sonicated for $6 \mathrm{~s}$ to achieve complete cell wall disruption (550 Sonic Dismembranator, Thermo Fisher Scientific). Western blot analysis was performed using 6, 8, and 12.5\% SDS-polyacrylamide gels with $40 \mu \mathrm{g}$ of protein loaded in every lane. On each gel, a pooled liver tissue control sample from one animal in our experiment was loaded to account for variation in experimental conditions over time. Transfer, blocking, and incubation with primary and secondary antibodies as well as imaging and densitometry were as previously described (Mann et al., 2016). Primary antibodies were purchased for the target proteins LC3B, ACC (Cell Signaling Technology, Danvers, MA), G6PC, HMGCS2, PC, CPT1A (Thermo Fisher Scientific), and PCK1 (Sigma-Aldrich, St. Louis, MO). Two proteins served as loading control: $\beta$-actin and $\beta$-tubulin (Cell Signaling Technology). All antibodies were tested for bovine reactivity by the manufacturer except those targeting 
LC3B, PC, and $\beta$-actin, for which cross-reactivity was predicted based on a sequence homology of $100 \%$.

\section{Liver Triglyceride and Glycogen Content}

Liver triglyceride content in $90 \mathrm{mg}$ of tissue was determined as previously described (Fry et al., 2018) following a modification of the Hantzsch condensation method and comparison with a triolein standard curve (Folch et al., 1957). Liver glycogen content was determined using a commercially available fluorometric assay (glycogen assay kit, Cayman Chemical, Ann Arbor, MI). Frozen tissue was weighed and $30 \mathrm{mg}$ was homogenized in $1 \mathrm{~mL}$ of ice-cold assay buffer with the addition of $10 \mu \mathrm{g} / \mathrm{mL}$ of leupeptin. The linearity of the assay was first tested using a series of 2 -fold dilutions. Samples were diluted 20-fold to fall in the middle of the standard curve. Samples were assayed in duplicate, and background samples were included for every sample to adjust for glucose that did not originate from glycogen hydrolysis. Fluorescence was measured using a Spectra Max M3 plate reader (Molecular Devices, Sunnyvale, CA) with 535-nm excitation and 590-nm emission wavelengths. The intra- and interassay coefficients of variation of the assay were 3.5 and $3.1 \%$, respectively.

\section{Analytical Approach}

The sample size of 8 animals in each group was determined as described previously for the main outcome of interest of this study, which was reduction in BHB concentration (Mann et al., 2017). Our main outcome in this part of the study was to be able to find a biologically significant reduction in liver triglycerides. Given this predetermined sample size of 8 paired observations in 4 groups, a chosen significance level of $\alpha=0.05$, and a desired power of $\beta \geq 0.95$, we calculated that this sample size would be sufficient to detect a difference between any of the treatments if the variance explained by the treatment effect would be at least $14.9 \%$ of the total variance in the model. This calculation was based on a presumed correlation between measurements within a cow of 0.5 and a repeated-measures ANOVA (G*Power version 3.1.9.2; Faul et al., 2007). Allocation to treatments was performed following the sequence obtained from a random number generator (Research Randomizer version 4.0; Urbaniak and Plous, 2012). For all outcomes of interest, statistical analyses were carried out with the software package SAS (version 9.4, SAS Institute, Cary, NC) using PROC MIXED. To account for the paired nature of the data, a repeated statement was included for the fixed effect of time point and the unstructured covariance structure chosen for all models. Fixed effects in the model included treatment group, time point, and their interaction. Days in milk at enrollment, BHB concentration at enrollment, and parity (dichotomized to parity 2 and $\geq 3$ ) were included as covariates to control for possible confounding due to these factors. After each model fit, homoscedasticity and normality of residuals were assessed and model assumptions were fulfilled in each case. In addition, and due to the small sample size, outlier statistics were generated with the INFLUENCE statement for the effect of cow, and cows were removed from the analysis if Cook's distance exceeded 0.5. Comparison for differences among groups and for each time point was controlled for multiple comparisons with the Tukey procedure. Least squares means and standard errors were plotted using Prism for Windows (GraphPad, version 7.03, GraphPad Software Inc., La Jolla, CA). Results are presented as least squares means \pm standard error unless otherwise specified.

\section{RESULTS}

\section{Description of Study Population}

On average, cows were enrolled (mean \pm SD) $5.3 \pm$ $1.5 \mathrm{~d}$ after calving with an average whole-blood BHB concentration of $1.4 \pm 0.2 \mathrm{mmol} / \mathrm{L}$. Cows weighed (mean $\pm \mathrm{SD}) 738 \pm 77 \mathrm{~kg}$ and produced an average of $36.5 \pm 7.6 \mathrm{~kg}$ of milk in the $2 \mathrm{~d}$ preceding enrollment. As previously described, no differences existed in distribution of parities, average DIM, BW, BCS, or BHB concentration at enrollment between groups (Mann et al., 2017).

\section{Hepatic Triglyceride and Glycogen Concentration}

Triglyceride concentration in liver biopsies was not different between the groups $(P=0.32$; Figure 1$)$ but increased from $10.6 \pm 1.2 \%$ to $11.9 \pm 1.3 \%$ across all groups over the study period (time $P=0.08$ ). Glycogen concentration was not different between groups $(P=$ $0.81)$ and did not change over time $(P=0.45$; Figure $1)$.

\section{Hepatic Gene Expression of Key Enzymes}

The relative gene expression of selected hepatic enzymes is summarized in Figure 2. Following outlier diagnostics, 1 cow in group CTRL was excluded from the analysis for $P C K 1$. An interaction between treatment group and time $(P=0.001)$ was found for the change of $P C$ in group GLU+PG, which decreased after treatment compared with pretreatment expression level (Figure 2). The gene expression of PCK1, HMGCS2, and $G 6 P C(P>0.16)$ was not different among treat- 
ment groups or over time. The gene expression of $A C C 1$ and $C P T 1 A$ decreased over the study period from $1.1 \pm$ 0.1 to $0.82 \pm 0.1$ (time $P=0.005$ ) and from $0.96 \pm 0.07$ to $0.85 \pm 0.06$ (time $P=0.05$ ), respectively.

\section{Hepatic Protein Abundance of Key Enzymes}

The results of Western blot densitometry for selected hepatic enzymes are shown in Figure 3. Outlier diagnostics led to the exclusion of the data of $1 \mathrm{cow}$ in
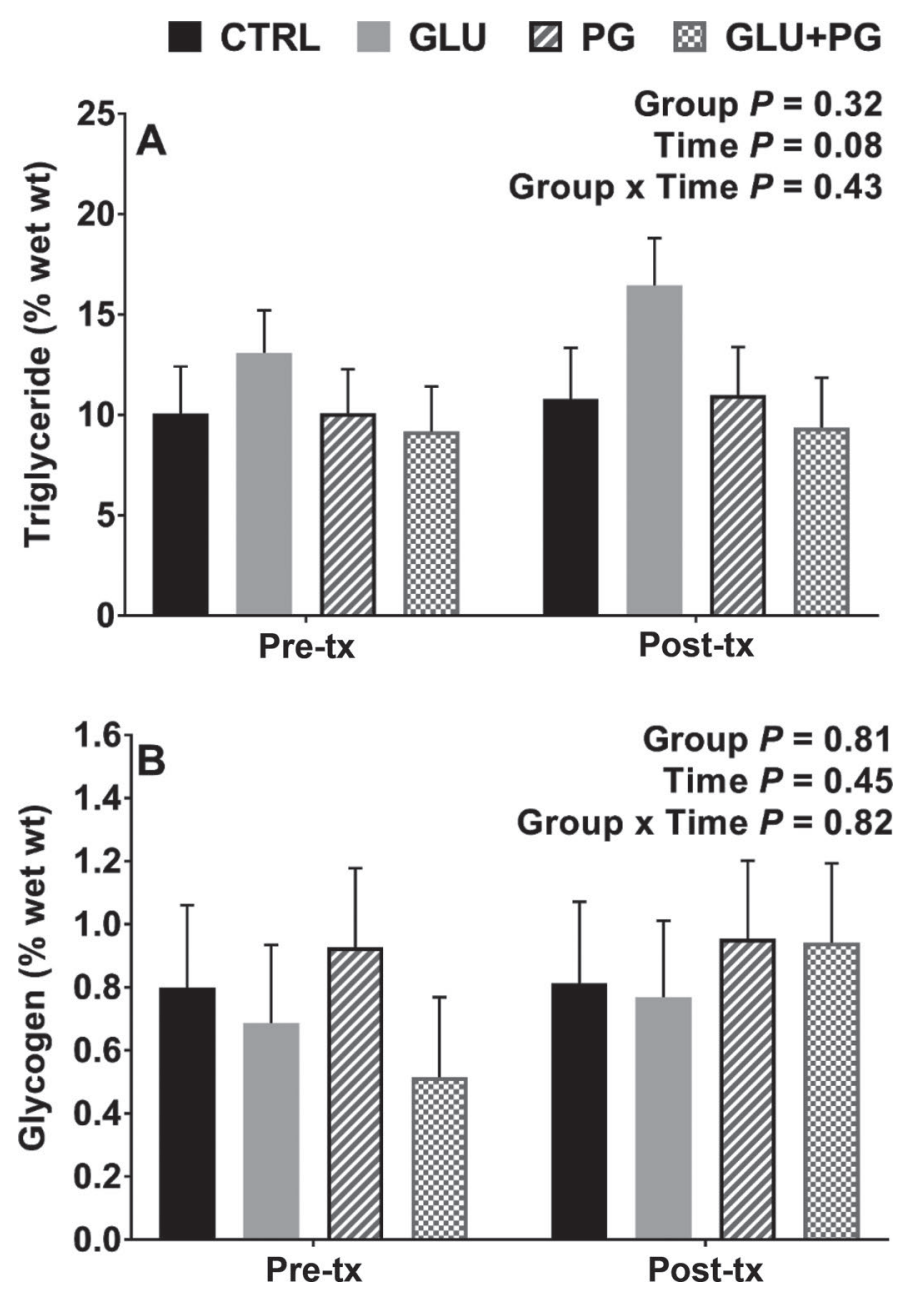

Figure 1. Least squares means for liver (A) triglyceride (\% of wet weight) and (B) glycogen (\% of wet weight) concentration at enrollment (pre-tx) and the day after completion of treatment (post-tx) in early postpartum hyperketonemic dairy cows randomly assigned to 1 of 4 treatments: GLU $(\mathrm{n}=8), 500 \mathrm{~mL}$ of a $50 \%$ glucose solution intravenously once daily for $3 \mathrm{~d}$; $\mathrm{PG}(\mathrm{n}=8), 300 \mathrm{~mL}$ of propylene glycol orally once daily for $3 \mathrm{~d}$; GLU+PG $(\mathrm{n}=8), 500 \mathrm{~mL}$ of a $50 \%$ glucose solution intravenously and $300 \mathrm{~mL}$ of propylene glycol orally once daily for $3 \mathrm{~d}$; CTRL $(\mathrm{n}=8)$, untreated control group. Error bars represent SEM. $P$-values of fixed effects of group, time point, and group $\times$ time point interaction are presented. Model covariates included in the respective models were DIM and BHB concentration in blood at enrollment as well as parity ( 2 vs. $\geq 3$ ). group PG for the LC3BII:I ratio and the data of a different cow in group PG for ACC protein expression.

Densitometry of PC protein expression showed an increase from $1.06 \pm 0.07$ to $1.2 \pm 0.07$ over the treatment period across all groups $(P=0.001)$. The amount of ACC protein decreased over time across all groups from $0.72 \pm 0.07$ to $0.54 \pm 0.05(P=0.003)$. Protein expression of PCK1, HMGCS2, G6PC, and CPT1A was not different among groups or over time $(P>0.19$; Figure 3$)$. The ratio of LC3B II:I showed an interaction between group and time, with a decrease in the ratio in group GLU+PG from the day of enrollment to the day after treatment completion (Figure 4).

\section{Blood Chemistry}

Results of the plasma chemistry analysis are summarized in Table 1. Plasma urea nitrogen and creatinine decreased from the day of enrollment to the day after completion of treatment in all groups from 11.5 \pm 0.5 to $9.7 \pm 0.6 \mathrm{mg} / \mathrm{dL}(P=0.02)$ and from 0.88 \pm 0.02 to $0.84 \pm 0.03 \mathrm{mg} / \mathrm{dL}(P=0.02)$, respectively. The liver enzymes aspartate aminotransferase (AST), succinate dehydrogenase (SDH), glutamate dehydrogenase (GLDH), and $\gamma$-glutamyl transferase (GGT) increased over this time frame in all groups from $103 \pm$ 4 to $117 \pm 5 \mathrm{U} / \mathrm{L}(P=0.001), 8.6 \pm 0.9$ to $11.9 \pm 1.2$ $\mathrm{U} / \mathrm{L}(P=0.001), 26 \pm 4$ to $40 \pm 5 \mathrm{U} / \mathrm{L}(P=0.005)$, and $17 \pm 1$ to $20 \pm 1 \mathrm{U} / \mathrm{L}(P<0.001)$, respectively.

Plasma total protein increased over time from $7.1 \pm$ 0.1 to $7.4 \pm 0.1 \mathrm{~g} / \mathrm{dL}$ and was lower overall in group GLU $(6.8 \pm 0.2 \mathrm{~g} / \mathrm{dL})$ than in group CTRL $(7.6 \pm 0.2$ $\mathrm{g} / \mathrm{dL} ; P=0.01)$. Globulin also increased over time from $3.6 \pm 0.1$ to $3.9 \pm 0.1 \mathrm{~g} / \mathrm{dL}$ and was lower overall in group GLU $(3.3 \pm 0.2 \mathrm{~g} / \mathrm{dL})$ than in group CTRL (4.1 $\pm 0.2 \mathrm{~g} / \mathrm{dL} ; P=0.03)$.

\section{DISCUSSION}

\section{Effects of Treatments on Hepatic Triglyceride and Glycogen Content}

Interestingly, triglyceride content did not decrease with treatment but increased slightly over time in all groups, which is consistent with the observed continued increase in liver triglycerides over the first $3 \mathrm{wk}$ postpartum (Vazquez-Añon et al., 1994). Given the association of negative energy balance, hyperketonemia, and fatty liver, it is not surprising that the average liver triglyceride content is reflective of clinical or severe fatty liver, defined as a concentration $\geq 10 \%$ on a wet basis (Gaal et al., 1983; Herdt, 1988; Bobe et al., 2004). Previous reports have shown a substantial decrease in liver triglyceride accumulation postpar- 
tum when 1 L of propylene glycol was administered for the last $10 \mathrm{~d}$ prepartum (Studer et al., 1993) and when energy balance was artificially increased by force feeding (Bertics et al., 1992). Others failed to show an influence on triglycerides when propylene glycol was administered in the first week postpartum (Pickett et al., 2003a) or when a combination of propionate, propylene glycol, and fat was given from d 14 before until d 21 after calving (Patton et al., 2004). When comparing different studies, one has to keep in mind that effects of propylene glycol are more pronounced when drenched compared with topdressing or feeding it in TMR, as reviewed by Nielsen and Ingvartsen (2004). Triglyceride content was significantly decreased when glucose was infused continuously over the first $12 \mathrm{~d}$ postpartum at a dose of $1 \mathrm{~kg} / \mathrm{d}$ (Brown and Allen,

\section{$\square$ CTRL GLU $\square$ PG 1 GLU+PG}
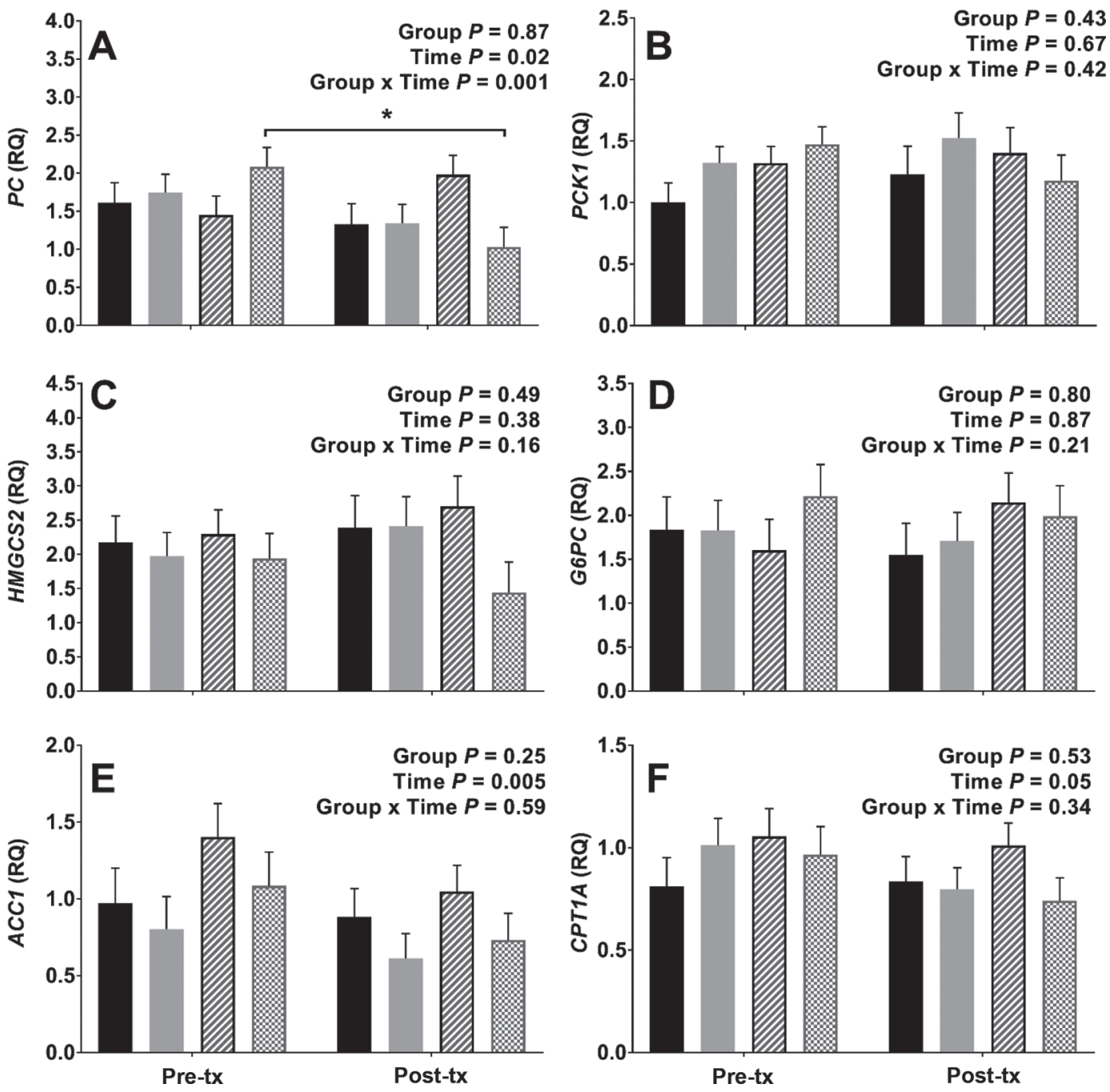

Figure 2. Least squares means for hepatic gene expression on the day of enrollment (pre-tx) and the day after completion of treatment (post-tx) of (A) pyruvate carboxylase $(P C),(\mathrm{B})$ phosphoenolpyruvate carboxykinase-1 (PCK1), (C) 3-hydroxy-3-methylglutaryl-CoA synthase-2 (HMGCS2), (D) glucose-6-phosphatase catalytic subunit (G6PC), (E) acetyl-CoA-carboxylase-1 (ACC1), and (F) carnitine palmitoyltransferase 1-A $(C P T 1 A)$ in early postpartum hyperketonemic dairy cows randomly assigned to 1 of 4 treatments: GLU $(\mathrm{n}=8), 500 \mathrm{~mL}$ of a $50 \%$ glucose solution intravenously once daily for $3 \mathrm{~d}$; PG $(\mathrm{n}=8), 300 \mathrm{~mL}$ of propylene glycol orally once daily for $3 \mathrm{~d}$; GLU+PG (n = 8), $500 \mathrm{~mL}$ of a $50 \%$ glucose solution intravenously and $300 \mathrm{~mL}$ of propylene glycol orally once daily for $3 \mathrm{~d}$; CTRL ( $=8 ; 1$ animal excluded from PCK1 analysis), untreated control group. Error bars represent SEM. $P$-values of fixed effects of group, time point, and group $\times$ time point interaction are presented. Model covariates were DIM and BHB concentration in blood at enrollment as well as parity $(2$ vs. $\geq 3)$. RQ $=$ relative gene expression. * denotes group differences $(P<0.05)$ between time points controlling for all pairwise comparisons with the Tukey procedure. 
$\square$ CTRL GLU $\square$ PG 9 GLU+PG
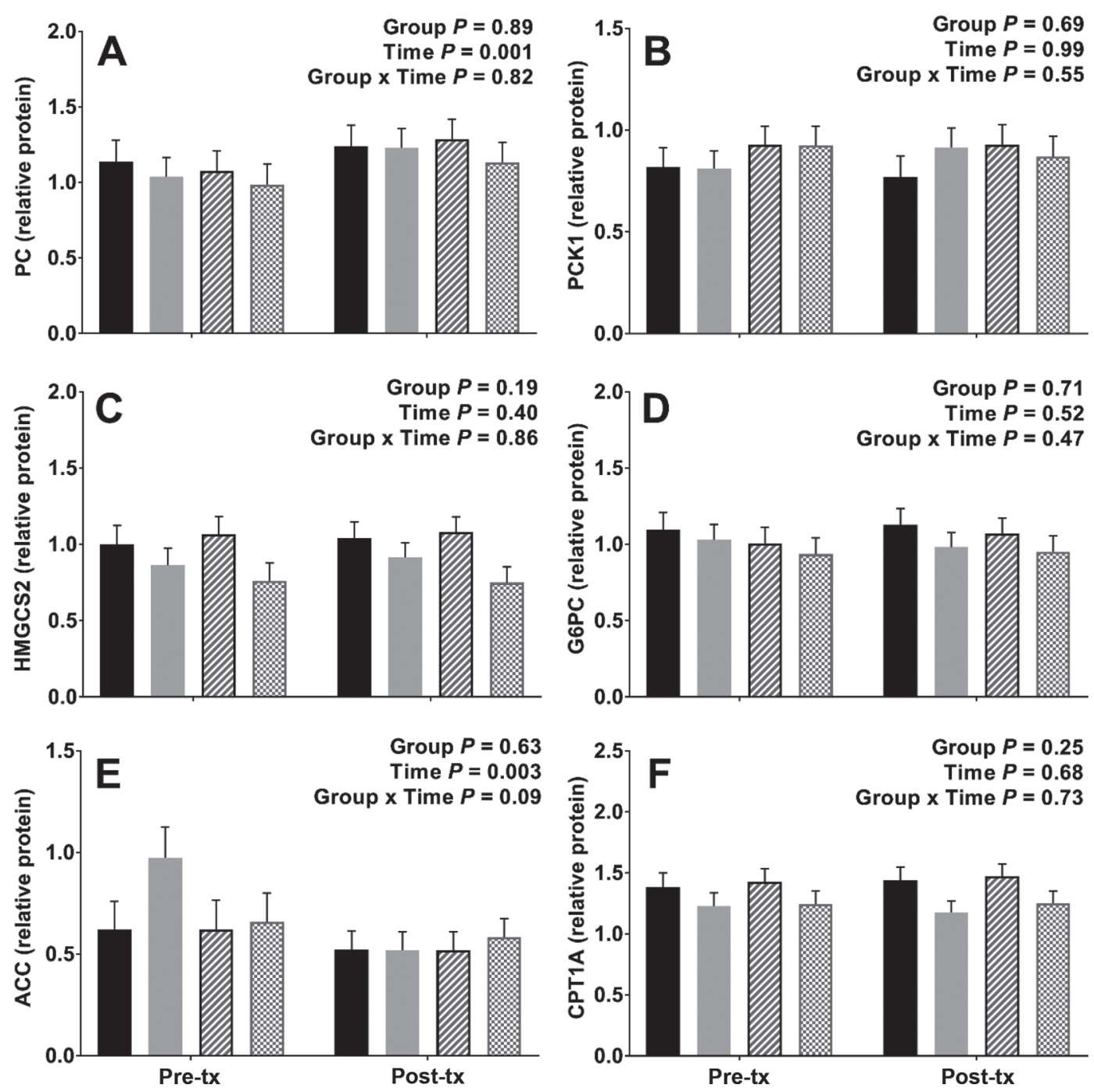

Figure 3. Least squares means for relative hepatic protein expression determined by immunoblotting on the day of enrollment (pre-tx) and the day after completion of treatment (post-tx) of (A) pyruvate carboxylase (PC), (B) phosphoenolpyruvate carboxykinase 1 (PCK1), (C) 3-hydroxy-3-methylglutaryl-CoA synthase 2 (HMGCS2), (D) glucose-6-phosphatase (G6PC), (E) acetyl-CoA-carboxylase (ACC, all isoforms), and $(\mathrm{F})$ carnitine palmitoyltransferase 1A (CPT1A) in early postpartum hyperketonemic dairy cows randomly assigned to 1 of 4 treatments: GLU ( $\mathrm{n}=8), 500 \mathrm{~mL}$ of a $50 \%$ glucose solution intravenously once daily for $3 \mathrm{~d}$; PG $(\mathrm{n}=8), 300 \mathrm{~mL}$ of propylene glycol orally once daily for $3 \mathrm{~d}$; GLU+PG $(\mathrm{n}=8), 500 \mathrm{~mL}$ of a $50 \%$ glucose solution intravenously and $300 \mathrm{~mL}$ of propylene glycol orally once daily for $3 \mathrm{~d}$; CTRL (n = 8), untreated control group. Error bars represent SEM. $P$-values of fixed effects of group, time point, and group $\times$ time point interaction are presented. Model covariates were DIM and BHB concentration in blood at enrollment as well as parity ( 2 vs. $\geq 3)$.

2013). To our knowledge, no study has investigated the effect of once daily intravenous glucose administration on liver triglyceride content of hyperketonemic animals. We conclude that a 3 -d treatment course of intravenous glucose, oral propylene glycol, or both is insufficient to prevent further accumulation of triglyceride in hyperketonemic animals.

Liver glycogen reaches a nadir on d 1 postpartum but remains unchanged between $\mathrm{d} 7$ and 21 postpartum in the absence of treatments (Vazquez-Añon et al., 1994).
The concentration of liver glycogen of approximately $1 \%$ wet weight (after control of baseline glucose content) is consistent with previous reports in the first week postpartum (Pickett et al., 2003b; Gonzalez and Rosendo, 2013). None of the treatments altered the liver glycogen content in comparison with the untreated control. In contrast, Pickett et al. (2003a) found that liver glycogen concentration in samples taken on d 7 postpartum was higher in cows receiving $500 \mathrm{~mL}$ of an oral propylene glycol drench for $7 \mathrm{~d}$ compared with control cows 

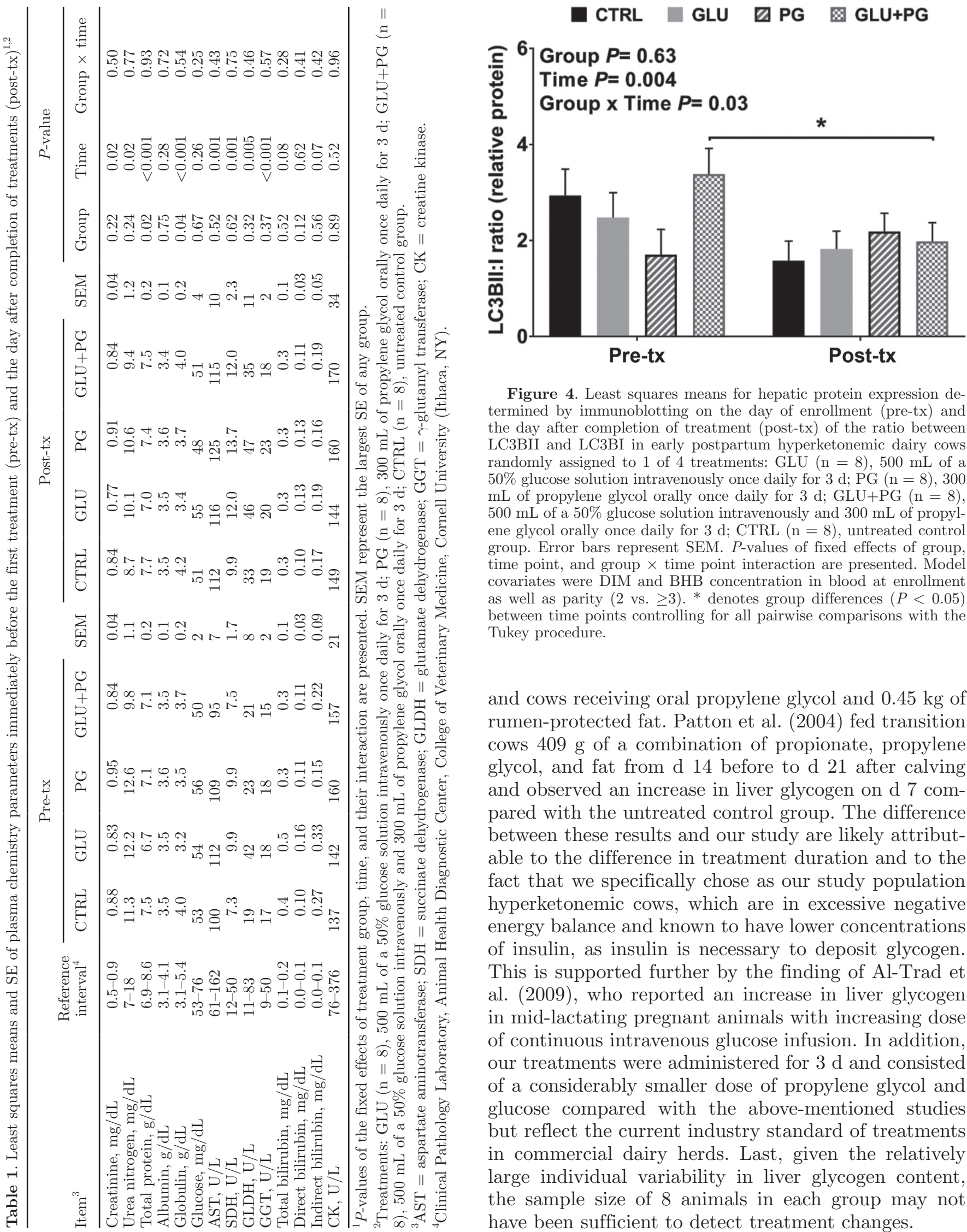

Figure 4. Least squares means for hepatic protein expression determined by immunoblotting on the day of enrollment (pre-tx) and the day after completion of treatment (post-tx) of the ratio between LC3BII and LC3BI in early postpartum hyperketonemic dairy cows randomly assigned to 1 of 4 treatments: GLU $(\mathrm{n}=8), 500 \mathrm{~mL}$ of a $50 \%$ glucose solution intravenously once daily for $3 \mathrm{~d}$; $\mathrm{PG}(\mathrm{n}=8), 300$ $\mathrm{mL}$ of propylene glycol orally once daily for $3 \mathrm{~d}$; GLU+PG $(\mathrm{n}=8)$, $500 \mathrm{~mL}$ of a $50 \%$ glucose solution intravenously and $300 \mathrm{~mL}$ of propylene glycol orally once daily for $3 \mathrm{~d}$; CTRL $(\mathrm{n}=8)$, untreated control group. Error bars represent SEM. $P$-values of fixed effects of group, time point, and group $\times$ time point interaction are presented. Model covariates were DIM and BHB concentration in blood at enrollment as well as parity ( 2 vs. $\geq 3)$. ${ }^{*}$ denotes group differences $(P<0.05)$ between time points controlling for all pairwise comparisons with the Tukey procedure.

and cows receiving oral propylene glycol and $0.45 \mathrm{~kg}$ of rumen-protected fat. Patton et al. (2004) fed transition cows $409 \mathrm{~g}$ of a combination of propionate, propylene glycol, and fat from d 14 before to d 21 after calving and observed an increase in liver glycogen on d 7 compared with the untreated control group. The difference between these results and our study are likely attributable to the difference in treatment duration and to the fact that we specifically chose as our study population hyperketonemic cows, which are in excessive negative energy balance and known to have lower concentrations of insulin, as insulin is necessary to deposit glycogen. This is supported further by the finding of Al-Trad et al. (2009), who reported an increase in liver glycogen in mid-lactating pregnant animals with increasing dose of continuous intravenous glucose infusion. In addition, our treatments were administered for $3 \mathrm{~d}$ and consisted of a considerably smaller dose of propylene glycol and glucose compared with the above-mentioned studies but reflect the current industry standard of treatments in commercial dairy herds. Last, given the relatively large individual variability in liver glycogen content, the sample size of 8 animals in each group may not have been sufficient to detect treatment changes. 


\section{Effects of Treatments on Hepatic Gene and Protein Expression of Key Enzymes}

The 3 enzymes PC, PCK-1, and G6PC are important regulating enzymes in gluconeogenesis (Aschenbach et al., 2010). Pyruvate carboxylase catalyzes the reaction from pyruvate to oxaloacetate and increases the oxaloacetate availability, and the upregulation of this enzyme in the bovine promotes gluconeogenesis when intake or energy balance are compromised (Aschenbach et al., 2010). Consequently, the abundance of $P C$ and the activity of this enzyme have been found to increase postpartum and remain elevated between d 1 and 28 postpartum in liver samples from 38 transition cows (Greenfield et al., 2000). The results of our study showed that the gene expression of $P C$ decreased in cows in group GLU+PG alone, whereas protein expression was increased in all groups at the second biopsy. These results show that there can be a significant discrepancy between gene and protein expression because mRNA stability and translation are regulated by numerous posttranscriptional mechanisms (Day and Tuite, 1998). Al-Trad et al. (2010b) observed a downregulation of $P C$ mRNA expression and numerically decreased PC activity with a high glucose dose of $30 \%$ of $\mathrm{NE}_{\mathrm{L}}$ requirements (approximately $2.65 \mathrm{~kg}$ of glucose), whereas the enzyme activity and gene expression were not different when up to $20 \%$ of $\mathrm{NE}_{\mathrm{L}}$ requirements were supplied by intravenous glucose infusion. It is likely that the physiological increase in PC activity in the transition period can be affected only by supplying a dose of glucose that is significantly higher than the one provided here.

The cytosolic enzyme PCK-1 regulates the entry of precursors into the gluconeogenic pathway and is required for gluconeogenesis from oxaloacetate; thus, the activity of this enzyme in the face of low oxaloacetate availability postpartum may further compromise the activity of the Krebs cycle (Aschenbach et al., 2010). Given the presumed relative lack of hepatic oxaloacetate in hyperketonemic cows (White, 2015), it is not surprising that PCK-1 did not change over time and that we observed no effect of treatment. We observed no effect of time or treatment on the abundance of G6PC. The role of this enzyme in gluconeogenesis is to release glucose from hepatocytes following synthesis (Aschenbach et al., 2010). In accordance with our results, no difference was observed in the activity of gene expression of hepatic $P C K 1$ or $G 6 P C$ or the activity of these 2 gluconeogenic enzymes at any dose level of intravenous glucose (Al-Trad et al., 2010b). Zhang et al. (2015) measured the gene expression of PCK1, G6PC, and $P C$ after an 8-h postruminal infusion with $160.4 \mathrm{~g}$ of sodium propionate or $150.4 \mathrm{~g}$ of glucose and found that PCK1 and G6PC expression tended to be lower in the group infused with glucose than in the group infused with propionate. It is possible that such acute effects on the gene expression of these enzymes might occur within several hours after our treatments were administered, but no change was detectable $24 \mathrm{~h}$ after the last treatment.

Acetyl-CoA carboxylase catalyzes the reaction from acetyl-CoA to malonyl-CoA in fatty acid biosynthesis. Both gene expression of $\mathrm{ACC} 1$ and protein expression of ACC decreased over the course of the study in all groups, indicating that the rate of de novo lipid synthesis in the liver decreased regardless of treatment.

Located on the outer mitochondrial membrane, CPT1A catalyzes the reaction of long-chain fatty acids with carnitine to a transportable form, an important step in determining the transport rate for $\beta$-oxidation (Al-Trad et al., 2010a). We found that the gene expression of CPT1A decreased in all groups in the first $4 \mathrm{~d}$ after enrollment, likely reflecting a physiological adaptation to a decreased hepatic uptake of circulating fatty acids after the peak of lipolysis at and immediately after calving. Dann and Drackley (2005) found that the highest activity of CPT1 coincided with the peak in serum fatty acids immediately after calving. Despite the numerically increased activity of CPT1 in a group of cows with ketosis 2 wk after calving, no clear relationship was found between the degree of ketosis and CPT1 activity (Dann and Drackley, 2005). In our study, the gene and protein expression of this enzyme was not affected by intravenous glucose or oral propylene glycol treatment. This is in accordance with the lack of difference in hepatic mitochondrial CPT activity measured in vitro and no change in the relative mRNA expression in hepatic CPT-1A after an 8-d infusion of intravenous glucose in an amount to supply $10 \%$ of the $\mathrm{NE}_{\mathrm{L}}$ requirements of mid-lactation cows (Al-Trad et al., 2010a).

3-Hydroxy-3-methylglutaryl-CoA synthase is the rate-limiting enzyme in the ketogenic pathway ( $\mathrm{Li}$ et al., 2012). Neither mRNA abundance nor protein expression of HMGCS2 were associated with treatment or time. Graber et al. (2010) measured gene expression of HMGCS2 at 3 time points in the transition period and did not observe differences between 3 wk prepartum and 4 wk postpartum despite an increase to approximately double the BHB concentrations at 4 wk postpartum. The results of this limited number of studies on gene and protein expression of HMGCS2 in bovine liver suggest that the abundance of this enzyme does not change markedly over time or after BHB concentrations are reduced by common hyperketonemia treatments.

The ratio of the protein LC3B II:I is a marker for autophagy, a catabolic cellular process that is upregulated under conditions of nutrient deficit to degrade macro- 
molecules and aid in improving nutrient balance (Pavel and Rubinsztein, 2017). To our knowledge, autophagy in hepatocytes of hyperketonemic cows has not been described, but is likely upregulated compared with other stages of lactation when nutrient balance is more favorable. The decrease in this autophagy marker in group GLU+PG compared with all other groups may be an indication that the short-term supply of both glucose and propylene glycol is able to reduce the rate of cytoplasmic degradation.

\section{Effects of Treatments on Blood Chemistry}

Changes in plasma chemistry within the reference ranges are likely not biologically important despite the small changes that occurred in all groups over time. Plasma urea nitrogen and creatinine decreased slightly, which may be a reflection of glomerular filtration rate or a decrease in muscle catabolism. Plasma urea nitrogen is also affected by protein intake and protein: energy ratio (Kwan et al., 1977). A small increase within the normal reference range in the liver enzymes AST, SDH, GLDH, and GGT occurred in all groups between the 2 sampling time points. We hypothesize that this small but detectable effect is attributable to the focally induced damage (AST, SDH, and GLDH) and reparative processes (GGT) in the hepatic tissue induced by the liver biopsy. An alternative explanation is that this change would have been observed in the absence of liver biopsy and is part of the hepatic adaptation to lactation and hyperketonemia, but this remains speculation in the absence of a group that did not have biopsies taken. Total protein and globulin increased, which may reflect a physiological postpartum increase (Piccione et al., 2011), a mild systemic inflammation associated with the transition period (Bionaz et al., 2007), or a localized hepatic inflammation secondary to the liver biopsy.

\section{Study Limitations}

The work described here and in Mann et al. (2017) was performed to describe the physiological response of postpartum hyperketonemic cows to different treatments, with cows being included in the study based on a cut-off of whole-blood BHB of $\geq 1.2 \mathrm{mmol} / \mathrm{L}$. We based this decision on previous work that showed that intervention with oral propylene glycol at this and higher concentrations of $\mathrm{BHB}$ at diagnosis improved health and production outcomes in postpartum dairy cows (McArt et al., 2011, 2012). Our goal was to describe potential treatment differences in our main outcomes of interest, which were liver triglyceride, glycogen, and expression of key enzymes in liver metabolism in hyperketonemic animals. A limitation of the sample size was that we could not test outcomes at different concentrations of BHB or test associations with health and production outcomes. However, the question of at which BHB concentrations cows are expected to benefit to a sufficient extent (clinically and economically) from each of the treatments described here and elsewhere remains to be addressed in field trials of sufficient sample size to test this hypothesis.

Our sample size for the described main outcome of interest (i.e., anticipated triglyceride content differences between groups after treatment) was limited to 8 paired observations in each of the 4 groups, and no difference was found among the treatments. In fact, the total variance explained by the treatment effect in the model was only $6.8 \%$ (i.e., approximately half of what we found in our power calculation to be necessary to declare a difference). This could have been due to the small magnitude of differences we measured and a proportionally larger variability in this study population. Given the observed variance explained by the treatment effect, a presumed correlation among repeated measurements within a cow of 0.5 , and the assumption that future similarly performed studies result in comparable results, a sample size of 16 animals in each of the 4 groups (64 animals total) would be needed to find differences between groups.

\section{CONCLUSIONS}

We described the association between 3 different hyperketonemia treatment strategies compared with an untreated control and liver triglyceride and glycogen content as well as plasma chemistry and gene and protein expression of enzymes involved in hepatic gluconeogenesis, fatty acid metabolism, and ketogenesis. We conclude that intravenous glucose and oral propylene glycol, commonly used treatments for hyperketonemia in postpartum dairy cows, administered alone or in combination for a duration of $3 \mathrm{~d}$ did not have important beneficial or detrimental effects on selected indicators of liver composition and function. However, although a total of 32 animals were enrolled in the study, the sample size of 8 animals per treatment may have been insufficient to detect small but biologically important treatment effects.

\section{ACKNOWLEDGMENTS}

This material is based on work that is supported by the National Institute of Food and Agriculture, USDA (Washington, DC), Animal Health and Disease Research Program under award number 36100-03618, made available to the College of Veterinary Medicine, 
Cornell University (Ithaca, NY). The authors thank Charlene Ryan, Stephanie Tarlowe, and Jamie Horstmann (Cornell University) for their invaluable assistance with data collection. We also thank the staff at the research dairy for the care of the animals used in this study.

\section{REFERENCES}

Al-Trad, B., K. Reisberg, T. Wittek, G. B. Penner, A. Alkaassem, G. Gäbel, M. Fürll, and J. R. Aschenbach. 2009. Increasing intravenous infusions of glucose improve body condition but not lactation performance in midlactation dairy cows. J. Dairy Sci. 92:56455658. https://doi.org/10.3168/jds.2009-2264.

Al-Trad, B., T. Wittek, G. Gabel, M. Furll, K. Reisberg, and J. R. Aschenbach. 2010a. Activity of hepatic but not skeletal muscle carnitine palmitoyltransferase enzyme is depressed by intravenous glucose infusions in lactating dairy cows. J. Anim. Physiol. Anim. Nutr. (Berl.) 94:685-695. https://doi.org/10.1111/j.1439-0396 2010.00993.x.

Al-Trad, B., T. Wittek, G. B. Penner, K. Reisberg, G. Gabel, M. Furll, and J. R. Aschenbach. 2010b. Expression and activity of key hepatic gluconeogenesis enzymes in response to increasing intravenous infusions of glucose in dairy cows. J. Anim. Sci. 88:29983008. https://doi.org/10.2527/jas.2009-2463.

Aschenbach, J. R., N. B. Kristensen, S. S. Donkin, H. M. Hammon, and G. B. Penner. 2010. Gluconeogenesis in dairy cows: The secret of making sweet milk from sour dough. IUBMB Life 62:869-877. https://doi.org/10.1002/iub.400.

Bauman, D. E., and W. B. Currie. 1980. Partitioning of nutrients during pregnancy and lactation: A review of mechanisms involving homeostasis and homeorhesis. J. Dairy Sci. 63:1514-1529.

Bertics, S. J., R. R. Grummer, C. Cadorniga-Valino, and E. E. Stoddard. 1992. Effect of prepartum dry matter intake on liver triglyceride concentration and early lactation. J. Dairy Sci. 75:1914-1922. https://doi.org/10.3168/jds.S0022-0302(92)77951-X.

Bionaz, M., E. Trevisi, L. Calamari, F. Librandi, A. Ferrari, and G. Bertoni. 2007. Plasma paraoxonase, health, inflammatory conditions, and liver function in transition dairy cows. J. Dairy Sci. 90:1740-1750. https://doi.org/10.3168/jds.2006-445.

Bobe, G., J. W. Young, and D. C. Beitz. 2004. Invited review: Pathology, etiology, prevention, and treatment of fatty liver in dairy cows. J. Dairy Sci. 87:3105-3124. https://doi.org/10.3168/jds .S0022-0302(04)73446-3.

Bonnet, M., L. Bernard, S. Bes, and C. Leroux. 2013. Selection of reference genes for quantitative real-time PCR normalisation in adipose tissue, muscle, liver and mammary gland from ruminants. Animal 7:1344-1353. https://doi.org/10.1017/S1751731113000475.

Brown, W. E., and M. S. Allen. 2013. Effects of intrajugular glucose infusion on feed intake, milk yield, and metabolic responses of early postpartum cows fed diets varying in protein and starch concentration. J. Dairy Sci. 96:7132-7142. https://doi.org/10.3168/ jds.2013-6636.

Dann, H. M., and J. K. Drackley. 2005. Carnitine palmitoyltransferase I in liver of periparturient dairy cows: Effects of prepartum intake, postpartum induction of ketosis, and periparturient disorders. J. Dairy Sci. 88:3851-3859. https://doi.org/10.3168/jds .S0022-0302(05)73070-8.

Dann, H. M., D. E. Morin, G. A. Bollero, M. R. Murphy, and J. K. Drackley. 2005. Prepartum intake, postpartum induction of ketosis, and periparturient disorders affect the metabolic status of dairy cows. J. Dairy Sci. 88:3249-3264. https://doi.org/10.3168/ jds.S0022-0302(05)73008-3.

Day, D. A., and M. F. Tuite. 1998. Post-transcriptional gene regulatory mechanisms in eukaryotes: An overview. J. Endocrinol. 157:361-371

Faul, F., E. Erdfelder, A. G. Lang, and A. Buchner. 2007. G*Power 3: A flexible statistical power analysis program for the social, behavioral, and biomedical sciences. Behav. Res. Methods 39:175-191.
Folch, J., M. Lees, and G. H. Sloane Stanley. 1957. A simple method for the isolation and purification of total lipids from animal tissues. J. Biol. Chem. 226:497-509.

Fry, M., B. Yao, C. Rios, S. Mann, C. Wong, J. A. McArt, D. Nydam, F. A. Leal Yepes, L. Viesselmann, A. Jordan, A. Geick, K. Goldin, and E. Behling-Kelly. 2018. Diagnostic performance of cytology for assessment of hepatic lipid content in dairy cattle. J. Dairy Sci. 101:1379-1387. https://doi.org/10.3168/jds.2017-12897.

Gaal, T., I. M. Reid, R. A. Collins, C. J. Roberts, and B. V. Pike. 1983. Comparison of biochemical and histological methods of estimating fat content of liver of dairy cows. Res. Vet. Sci. 34:245-248.

Gohary, K., M. W. Overton, M. Von Massow, S. J. LeBlanc, K. D. Lissemore, and T. F. Duffield. 2016. The cost of a case of subclinical ketosis in Canadian dairy herds. Can. Vet. J. 57:728-732.

Gonzalez, C. I., and O. Rosendo. 2013. Assessment of fatty liver syndrome and its predisposing factors in a dairy herd from Venezuela. ISRN Vet. Sci. 2013:191708. https://doi.org/10.1155/2013/ 191708.

Gordon, J. L., S. J. Leblanc, and T. F. Duffield. 2013. Ketosis treatment in lactating dairy cattle. Vet. Clin. North Am. Food Anim. Pract. 29:433-445. https://doi.org/10.1016/j.cvfa.2013.03.001.

Gordon, J. L., S. J. LeBlanc, D. F. Kelton, T. H. Herdt, L. Neuder, and T. F. Duffield. 2017. Randomized clinical field trial on the effects of butaphosphan-cyanocobalamin and propylene glycol on ketosis resolution and milk production. J. Dairy Sci. 100:3912-3921. https://doi.org/10.3168/jds.2016-11926.

Graber, M., S. Kohler, T. Kaufmann, M. G. Doherr, R. M. Bruckmaier, and H. A. van Dorland. 2010. A field study on characteristics and diversity of gene expression in the liver of dairy cows during the transition period. J. Dairy Sci. 93:5200-5215. https://doi.org/ 10.3168/jds.2010-3265.

Greenfield, R. B., M. J. Cecava, and S. S. Donkin. 2000. Changes in mRNA expression for gluconeogenic enzymes in liver of dairy cattle during the transition to lactation. J. Dairy Sci. 83:1228-1236. https://doi.org/10.3168/jds.S0022-0302(00)74989-7.

Herdt, T. H. 1988. Fatty liver in dairy cows. Vet. Clin. North Am. Food Anim. Pract. 4:269-287. https://doi.org/10.1016/S0749 -0720(15)31048-3.

Herdt, T. H. 2000. Ruminant adaptation to negative energy balance. Influences on the etiology of ketosis and fatty liver. Vet. Clin. North Am. Food Anim. Pract. 16:215-230.

Herdt, T. H., and R. S. Emery. 1992. Therapy of diseases of ruminant intermediary metabolism. Vet. Clin. North Am. Food Anim. Pract. 8:91-106.

Hughes, J. P. 1962. A simplified instrument for obtaining liver biopsies in cattle. Am. J. Vet. Res. 23:1111-1113.

Kwan, K., C. E. Coppock, G. B. Lake, M. J. Fettman, L. E. Chase, and R. E. McDowell. 1977. Use of urea by early postpartum Holstein cows. J. Dairy Sci. 60:1706-1724. https://doi.org/10.3168/ jds.S0022-0302(77)84095-2.

Li, P., X. B. Li, S. X. Fu, C. C. Wu, X. X. Wang, G. J. Yu, M. Long, Z. Wang, and G. W. Liu. 2012. Alterations of fatty acid beta-oxidation capability in the liver of ketotic cows. J. Dairy Sci. 95:1759-1766. https://doi.org/10.3168/jds.2011-4580.

Mann, S., A. Abuelo, D. V. Nydam, F. A. Leal Yepes, T. R. Overton, and J. J. Wakshlag. 2016. Insulin signaling and skeletal muscle atrophy and autophagy in transition dairy cows either overfed energy or fed a controlled energy diet prepartum. J. Comp. Physiol. B 186:513-525. https://doi.org/10.1007/s00360-016-0969-1.

Mann, S., F. A. L. Yepes, E. Behling-Kelly, and J. A. A. McArt. 2017. The effect of different treatments for early-lactation hyperketonemia on blood beta-hydroxybutyrate, plasma nonesterified fatty acids, glucose, insulin, and glucagon in dairy cattle. J. Dairy Sci. 100:6470-6482. https://doi.org/10.3168/jds.2016-12532.

McArt, J. A., D. V. Nydam, and G. R. Oetzel. 2012. A field trial on the effect of propylene glycol on displaced abomasum, removal from herd, and reproduction in fresh cows diagnosed with subclinical ketosis. J. Dairy Sci. 95:2505-2512. https://doi.org/10.3168/ jds.2011-4908.

McArt, J. A., D. V. Nydam, G. R. Oetzel, T. R. Overton, and P. A. Ospina. 2013. Elevated non-esterified fatty acids and beta- 
hydroxybutyrate and their association with transition dairy cow performance. Vet. J. 198:560-570. https://doi.org/10.1016/j.tvjl 2013.08.011.

McArt, J. A., D. V. Nydam, P. A. Ospina, and G. R. Oetzel. 2011. A field trial on the effect of propylene glycol on milk yield and resolution of ketosis in fresh cows diagnosed with subclinical ketosis. J. Dairy Sci. 94:6011-6020. https://doi.org/10.3168/jds.2011-4463.

McArt, J. A., D. V. Nydam, and M. W. Overton. 2015. Hyperketonemia in early lactation dairy cattle: A deterministic estimate of component and total cost per case. J. Dairy Sci. 98:2043-2054. https://doi.org/10.3168/jds.2014-8740.

Nielsen, N. I., and K. L. Ingvartsen. 2004. Propylene glycol for dairy cows: A review of the metabolism of propylene glycol and its effects on physiological parameters, feed intake, milk production and risk of ketosis. Anim. Feed Sci. Technol. 115:191-213. https://doi .org/10.1016/j.anifeedsci.2004.03.008.

Ospina, P. A., J. A. McArt, T. R. Overton, T. Stokol, and D. V. Nydam. 2013. Using nonesterified fatty acids and beta-hydroxybutyrate concentrations during the transition period for herd-level monitoring of increased risk of disease and decreased reproductive and milking performance. Vet. Clin. North Am. Food Anim. Pract. 29:387-412. https://doi.org/10.1016/j.cvfa.2013.04.003.

Ostrowska, M., B. Żelazowska, K. Słoniewski, Z. M. Kowalski, and L. Zwierzchowski. 2014. Technical note: Selecting the best references in gene expression experiments in liver of cows receiving glucogenic supplements during the transition period. J. Dairy Sci. 97:911-916. https://doi.org/10.3168/jds.2013-7220.

Patton, R. S., C. E. Sorenson, and A. R. Hippen. 2004. Effects of dietary glucogenic precursors and fat on feed intake and carbohydrate status of transition dairy cows. J. Dairy Sci. 87:2122-2129. https://doi.org/10.3168/jds.S0022-0302(04)70031-4.

Pavel, M., and D. C. Rubinsztein. 2017. Mammalian autophagy and the plasma membrane. FEBS J. 284:672-679. https://doi.org/10 $.1111 /$ febs.13931.

Piccione, G., V. Messina, A. Schembari, S. Casella, C. Giannetto, and D. Alberghina. 2011. Pattern of serum protein fractions in dairy cows during different stages of gestation and lactation. J. Dairy Res. 78:421-425. https://doi.org/10.1017/S0022029911000562.
Pickett, M. M., M. S. Piepenbrink, and T. R. Overton. 2003a. Effects of propylene glycol or fat drench on plasma metabolites, liver composition, and production of dairy cows during the periparturient period. J. Dairy Sci. 86:2113-2121. https://doi.org/10.3168/jds .S0022-0302(03)73801-6.

Pickett, M. M., M. S. Piepenbrink, and T. R. Overton. 2003b. Effects of propylene glycol or fat drench on plasma metabolites, liver composition, and production of dairy cows during the periparturient period. J. Dairy Sci. 86:2113-2121. https://doi.org/10.3168/jds .S0022-0302(03)73801-6.

Raboisson, D., M. Mounie, E. Khenifar, and E. Maigne. 2015. The economic impact of subclinical ketosis at the farm level: Tackling the challenge of over-estimation due to multiple interactions. Prev. Vet. Med. 122:417-425. https://doi.org/10.1016/j.prevetmed.2015 .07.010.

Studer, V. A., R. R. Grummer, S. J. Bertics, and C. K. Reynolds 1993. Effect of prepartum propylene glycol administration on periparturient fatty liver in dairy cows. J. Dairy Sci. 76:2931-2939. https://doi.org/10.3168/jds.S0022-0302(93)77633-X.

Tatone, E. H., T. F. Duffield, M. B. Capel, T. J. DeVries, S. J. LeBlanc, and J. L. Gordon. 2016. A randomized controlled trial of dexamethasone as an adjunctive therapy to propylene glycol for treatment of hyperketonemia in postpartum dairy cattle. J. Dairy Sci. 99:8991-9000. https://doi.org/10.3168/jds.2016-11358.

Urbaniak, G. C., and S. Plous. 2012. Research Randomizer. Version 4.0. Accessed Jan. 25, 2016. http://www.randomizer.org/form .htm.

Vazquez-Añon, M., S. Bertics, M. Luck, R. R. Grummer, and J. Pinheiro. 1994. Peripartum liver triglyceride and plasma metabolites in dairy cows. J. Dairy Sci. 77:1521-1528. https://doi.org/10 .3168/jds.S0022-0302(94)77092-2.

White, H. M. 2015. The role of TCA cycle anaplerosis in ketosis and fatty liver in periparturient dairy cows. Animals (Basel) 5:793-802. https://doi.org/10.3390/ani5030384.

Zhang, Q., S. L. Koser, B. J. Bequette, and S. S. Donkin. 2015. Effect of propionate on mRNA expression of key genes for gluconeogenesis in liver of dairy cattle. J. Dairy Sci. 98:8698-8709. https://doi .org/10.3168/jds.2015-9590. 